\author{
Mette Marit Forsmo Jenssen \\ Høgskolen i Innlandet \\ Thomas Nordahl \\ Høgskolen i Innlandet
}

DOI: http://doi.org/10.5617/adno.8144

\title{
Profesjonelle læringsfellesskap og læreres undervisningspraksis
}

\begin{abstract}
Sammendrag
Overordnet del av læreplanverket (LK20) gir uttrykk for at lærere skal være aktivt deltakende i profesjonelle læringsfellesskap med den hensikt å utvikle et innovativt og faglig lærersamarbeid som bidrar til økt lærerkompetanse og forbedret undervisningspraksis. Denne studien legger til grunn en retningsbestemt hypotese om at læreres tilhørighet i profesjonelle læringsfellesskap og deres profesjonstilfredshet påvirker deres undervisningspraksis. Studien er en tverrsnittstudie bestående av varians- og regresjonsanalyser av lærervurderte variabler fra 20 barneskoler i tidligere Hedmark fylke. Resultatene viser at lærere vurderer sin undervisningspraksis som relativt god, uavhengig av styrken de tillegger det profesjonelle læringsfellesskapet. Læreres vurdering av sin profesjonstilfredshet betyr mer enn profesjonelle læringsfellesskap når det gjelder deres vurdering av sin undervisningspraksis. Studien avdekker likevel noen mønstre og sammenhenger som kan tyde på at profesjonelle læringsfellesskap har betydning, og at studiens hypotese til dels kan bekreftes. Det er sterkere gjensidig forklaringskraft mellom variablene i skoler hvor lærere oppfatter at det er sterke profesjonelle læringsfellesskap. I disse skolene kan læreres vurdering av profesjonelle læringsfellesskap og egen profesjonstilfredshet sammen i større grad forklare deres vurdering av egen undervisningspraksis, sammenlignet med skoler hvor profesjonelle læringsfellesskap vurderes som svake. Det er vesentlig å forstå utvikling av profesjonelle læringsfellesskap som noe mer enn å redusere den privatpraktiserende lærers innflytelse. Det handler også i stor grad om å utfordre og endre både kollektive og individuelle verdier, oppfatninger og handlingsmønstre. Skolekulturen har sannsynligvis betydning for hvordan man opptrer som enkeltlærer i møte med elevene.
\end{abstract}

Nøkkelord: profesjonelle læringsfellesskap, profesjonstilfredshet, læreres undervisningspraksis, skolekultur

\section{Professional learning communities and teachers' teaching practices}

\begin{abstract}
The core curriculum in the Norwegian National Curriculum expresses that teachers must actively take part in professional learning communities to develop an innovative and professional teacher collaboration that contributes to increased teacher competence and
\end{abstract}


improved teaching practice. This study is based on a directional hypothesis that teachers' affiliation in professional learning communities and teachers' self-confidence influence their teaching practices. This is a cross-sectional study, consisting of analyses of variance and regression of teacher-assessed variables from 20 primary schools in former Hedmark county. The results show that teachers consider their teaching practice to be relatively good, regardless of the strength they attribute to the professional learning community. Teachers' assessment of their self-confidence is more important than professional learning communities when it comes to their assessment of their teaching practices. However, the study reveals findings that indicate that professional learning communities are important, and the hypothesis of the study can be partially confirmed. There is stronger mutual explanatory power between the variables in schools where teachers perceive strong professional learning communities. In these schools, professional learning communities and teachers' self-confidence together can to a greater extent explain their assessment of their own teaching practice, compared to schools where professional learning communities are assessed as weak. It is essential to understand the development of professional learning communities as something more than reducing the influence of teachers as solo practitioners. Challenging and changing both collective and individual values, perceptions and patterns of action are also key factors. The school culture probably has an impact on how one acts as solo practitioners together with the students.

Keywords: professional learning communities, self-confidence, teachers' teaching practices, school culture

\section{Innledning}

Den kollektive dimensjonen av lærerrollen har de siste årene fått økt oppmerksomhet, og overordnet del av læreplanverket for Kunnskapsløftet 2020 gir tydelige føringer på at ansatte i skolen skal være aktivt deltakende i profesjonelle læringsfellesskap og bidra til å utvikle skolen til en lærende organisasjon (Kunnskapsdepartementet, 2017). I dette ligger det blant annet at lærere, ledere og andre ansatte skal utvikle et kollektivt samarbeid som går utover koordinering og praktisk tilrettelegging av undervisning. Det legges vekt på et profesjonsfaglig fellesskap hvor det reflekteres over felles verdier, innstillinger og oppfatninger som eksisterer, og at man i fellesskap vurderer og videreutvikler pedagogisk praksis (Kunnskapsdepartementet, 2017). Føringene støttes av studier som viser at sterke profesjonelle læringsfellesskap bidrar til et innovativt og faglig lærersamarbeid som øker sannsynligheten for styrket lærerkompetanse og forbedret undervisning (Louis \& Marks, 1998; OECD, 2010). Denne studien følger dette resonnementet og legger til grunn en hypotese om at lærere i kollektivt orienterte skoler med sterke profesjonelle læringsfellesskap opplever høyere grad av profesjonstilfredshet og har bedre forutsetninger for å utøve god undervisningspraksis, sammenlignet med lærere i skoler hvor det profesjonelle læringsfellesskapet er svakere. Studiens to forskningsspørsmål er som følger: 
1) Har det profesjonelle læringsfellesskapet ulik forklaringskraft på læreres undervisningspraksis i skoler med sterke og svake profesjonelle læringsfellesskap, og eventuelt i hvilken grad?

2) Kan profesjonelle læringsfellesskap og læreres profesjonstilfredshet forklare læreres undervisningspraksis, og eventuelt på hvilken måte?

Forskningsspørsmålene baseres på lærervurderte variabler, og dette innebærer læreres oppfatninger av det profesjonelle læringsfellesskapet ved sin skole, sin vurdering av egen profesjonstilfredshet samt sin vurdering av egen undervisningspraksis. I forskningsspørsmålene ligger det en antakelse om at det er en sammenheng mellom variablene og en retningsbestemt hypotese, men denne antakelsen uttrykker ingen ensidig årsaksforklaring. Hypotesen er at læreres tilhørighet i profesjonelle læringsfellesskap og læreres profesjonstilfredshet påvirker læreres undervisningspraksis. Studien vil således være et kunnskapsbidrag til skolenes arbeid med å imøtekomme nasjonale føringer om profesjonelle læringsfellesskap som strategi for å forbedre undervisningspraksis (Kunnskapsdepartementet, 2017). Store deler av forskningen på området er tilknyttet internasjonale studier, og denne studien vil således være et viktig forskningsbidrag i norsk kontekst.

\section{Tidligere forskning}

Det har vært forsket i mange tiår på organisatoriske faktorer som påvirker læreres læring og undervisningspraksis (Grosin, 1991, 2004; Rutter et al., 1979). En tilnærming har vært å studere hvilken betydning den kulturen som eksisterer i den enkelte skole, har for lærerens undervisning (Hargreaves, 1997). Skolekulturen kan forstås som de felles verdier og oppfatninger som finnes i skolen og som legger klare rammer for lærerens praksis. Denne kulturen har også vært omtalt som skolens etos (Rutter et al., 1979), skolekoden (Arfwedson, 1984) og skolens klima (Grosin, 1991).

Flere studier viser imidlertid at det er store variasjoner mellom skoler når det gjelder skolekultur og måten lærere samarbeider på (Arfwedson, 1984; Jenssen, 2020; Nordahl et al., 2018; OECD, 2010). Arfwedson (1984) søkte i sin tid etter kjennetegn ved den svenske enhetsskolen og fant at det ikke eksisterte én skole, men mange forskjellige skoler forklart av kulturforskjeller: «Lærerne ved forskjellige skoler danner ulike individuelle og kollektive handlingsmønster, samt en for hver skole spesifikk arbeidsberedskap (kode) for å møte nærsamfunnets krav» (Arfwedson, 1984, s. 16). En norsk studie av Jenssen (2020) viser store forskjeller mellom grunnskoler når det gjelder læreres oppfatninger av samarbeidskulturen, men også at variasjonen er stor innenfor den enkelte skole. Disse funnene indikerer kompleksiteten som ligger i det å utvikle skolen som organisasjon og forbedre den pedagogiske praksisen. Robinson (2018) påpeker i sin forskning at det er mange faktorer som både fremmer og hemmer endring og trekker blant annet frem sterke normer for profesjonell autonomi som et mulig hinder for at etablert undervisningspraksis blir utfordret. Hun knytter begrensningen dette medfører til 
Argyris og Schöns (1996) handlingsteorier, og fremhever at forutsetningen for å lykkes er at det utvikles en engasjementstilnærming og et gjensidig samarbeid mellom aktørene i organisasjonen knyttet til kritisk vurdering og eventuell revidering av eksisterende handlingsteorier (Robinson, 2018). Det er når lærere utfordrer hverandres eksisterende handlinger og de verdier som ligger til grunn for handlingene, at det utvikles kompetanse på en slik måte at kunnskap omsettes til ny pedagogisk praksis (Argyris \& Schön, 1996; Robinson, 2018).

Det er gjort en rekke studier som finner klare sammenhenger mellom profesjonelle læringsfellesskap og endringer i skolenes samarbeidskultur, og flere studier kan i tillegg dokumentere sammenhenger mellom profesjonelle læringsfellesskap og læreres undervisningskvalitet (Vescio et al., 2008). Louis og Marks (1998) fant i en omfattende studie av 24 skoler med god resultatutvikling at lærere som tilhørte profesjonelle læringsfellesskap viste sterkere engasjement og støtte til elevene, og i større grad var opptatt av dybdelæring og kritisk tenkning i sin undervisningspraksis. Dunne et al. (2000) gjennomførte en longitudinell komparativ studie av 62 amerikanske skoler, hvorav 12 skoler deltok i et toårig skoleutviklingsprogram med vekt på utvikling av profesjonelle læringsfellesskap. Studien fant signifikante forskjeller mellom lærere fra deltakende skoler og de som ikke deltok. Lærere som deltok i profesjonelle læringsfellesskap endret holdning fra å være opptatt av gjennomføring av undervisning, til en mer elevsentrert undervisning med vekt på elevenes mestring. Videre fant en studie av Louis (2015) at lærere i sterke profesjonsfellesskap har større sannsynlighet for å utøve undervisning som utvikler elevers læringsstrategier, selvstendighet og selvregulert læring.

Mye tyder på at internasjonale studier kan omsettes til norske forhold. Ifølge Laursen (2015) er likhetene flere enn ulikhetene, og klassiske grunnkvaliteter for god undervisning er de samme på tvers av landegrenser. Dette bekreftes blant annet av Dahl et al. (2004) som fant klare sammenhenger mellom skolekultur og læreres endringsvilje da de evaluerte satsingen på kvalitetsutvikling i norsk grunnskole fra 2000 til 2003. Blant de 1200 skolene de studerte var det større sannsynlighet for at lærere var endringsvillige og at elevene oppnådde bedre læringsresultater i skoler med en kollektivt orientert kultur.

Tidligere forskning styrker grunnlaget for denne studiens hypotese om at profesjonsfellesskapet står sentralt for utvikling av lærerkompetanse og god undervisningspraksis. For å analysere og diskutere studiens datagrunnlag benyttes det konseptuelle rammeverket om profesjonelle læringsfellesskap som omfatter både kollektive læringsprosessforløp og kjennetegn ved organisatoriske læringskulturer innenfor utdanningssektoren (Louis, 2008). 


\section{Teoretisk rammeverk}

\section{Profesjonelle læringsfellesskap}

Profesjonelle lceringsfellesskap er et overordnet begrep for kollektive læringsprosesser og kjennetegn ved organisasjonskulturer i utdanningssektoren (Fullan, 2014; Hargreaves \& Fullan, 2014; Louis, 2008). Begrepet kan forstås i lys av definisjonen til DuFour et al. (2010, s. 11) som «an ongoing process in which educators work collaboratively in recurring cycles of collective inquiry and action research to achieve better results for the students they serve». Prosessen kan også knyttes til andre teoretiske tilnærminger som blant annet kunnskapsmobilisering (Levin, 2013), som innenfor teori om organisasjonslæring er et uttrykk for at man i fellesskap mobiliserer kunnskap hos den enkelte og som deles med andre (Crossan et al., 1999).

Profesjonelle læringsfellesskap gir muligheter for organisatorisk innovasjon og problemløsing ved kollektiv kunnskapstilegnelse, og ved at det overføres kunnskap på tvers av grupper og individer innad i organisasjonen (Easterby-Smith et al., 2008; Huber, 1991). Et kjennetegn ved sterke profesjonelle læringsfellesskap er at alle lærere har et felles forpliktende ansvar for alle elevene ved skolen, også de man ikke selv underviser (Stoll et al., 2006). Videre eksisterer det et utviklingsorientert og engasjerende samarbeid om både undervisning og elever, og samhandling og kritisk refleksjon står sentralt. Ved å involvere seg i sine kollegers utfordringer erkjenner man at engasjementet har en verdi for både elevers læring, lærerens profesjonstilfredshet, samt skolens kollektive kompetanse.

I tilknytning til profesjonelle læringsfellesskap er det gjort studier av lærerens self-confidence, et engelsk uttrykk for lærerens følelsesmessige balanse i profesjonsutøvelsen og trygghet og tillit til seg selv i utøvelse av undervisningspraksis (Holland et al., 2012). Donohoo (2017) løfter dette videre til en kollektiv dimensjon og læreres kollektive mestringstro, omtalt som collective teacher efficacy. Ved å arbeide i sterke profesjonelle fellesskap utvikles en felles mestringstro på at man sammen kan løfte alle elevers læring. Kollektiv mestringstro øker sannsynligheten for at lærere utviser høyere engasjement, yter større innsats, prøver ut nye metoder og tilrettelegger undervisningen med positive forventninger til alle elevers utvikling (Donohoo, 2017). Denne dynamiske forståelsen av læreres læring understøttes av Opfer og Pedder (2011) som belyser betydningen av å fokusere på gjensidige påvirkninger i og mellom alle nivåer i organisasjonen. Ifølge Opfer og Pedder (2011) bidrar en kollektiv kunnskapsmobilisering over tid til tilfredshet og opplevelse av profesjonsutvikling.

\section{Profesjonelle læringsfellesskap og endring av læreres undervisningspraksis}

En forutsetning for effektive profesjonelle læringsfellesskap er at engasjementet ikke begrenses til refleksjon og felles intensjoner, men en felles forståelse av at endring av resultater forutsetter endring av praksis (DuFour \& Marzano, 2015). 
Argyris og Schön (1996) belyser spennet mellom intensjoner og praksisendring ved å skille mellom to typer handlingsteorier. Intensjonene uttrykkes gjennom de uttalte teoriene som omfatter tanker, handlinger og de verdiene vi ønsker å identifisere oss med. De implisitte og anvendte teoriene, også kalt bruksteoriene, er de som faktisk tas i bruk og styrer våre handlinger. Det kan være langt enklere i et kollegium å være enig om intensjonene enn å gjennomføre dem i praksis (Argyris \& Schön, 1996). I den grad det er et misforhold mellom de uttalte teoriene og bruksteoriene, og handlingene ikke samsvarer med egne antakelser, kan sterke profesjonelle læringsfellesskap bidra til å utfordre og redusere dette misforholdet og bidra til dobbelkretslæring. Begrepet dobbelkretslæring refererer til de to kretsene som forbinder de observerte konsekvensene av handlingen med de grunnleggende verdiene som ligger til grunn for utfordringene som eksisterer (Argyris \& Schön, 1996, s. 21). Slik vil dobbelkretslæring, i motsetning til enkelkretslæringens enkle antakelser og endringer av handlinger, utforske og evaluere verdier, holdninger, innstillinger og egeninteresser som styrer handlingene og på denne måten være en betingelse for å kunne omsette kunnskap til ny pedagogisk praksis (Argyris \& Schön, 1996).

Lærerens undervisning foregår i klasserommet i møte med elevene, og læreren opptrer ofte alene i dette møtet. Hvorvidt dette møtet er vellykket og bidrar til elevers læring, avhenger av flere faktorer. Både lærer og elev er en del av en organisasjon med gitte mentale modeller. Det er læreren som forventes å være den ansvarlige, den som har kunnskap og stiller viktige spørsmål i tråd med læreplanen, mens eleven er den underordnede som skal finne svarene og erfare læring. Dette asymmetriske forholdet kan både gi muligheter og være et hinder for å endre og forbedre læringsprosessen (Louis, 2015; Sarason, 1996). Sarason (1996) problematiserer utviklingsprosesser i lys av maktforholdet som eksisterer mellom lærer og elev. Utfordringen ligger i hvordan læreren som autoritet og med sin iboende vilje til å påvirke, kan utøve sin makt på en slik måte at elevene opplever eierskap til, og blir selvregulert i egen læreprosess. Oettingen (2001, s. 9) beskriver det som et pedagogisk paradoks og et stort dilemma at man gjennom ytre påvirkninger skal bidra til at et menneske ikke lar seg bestemme av ytre påvirkninger. Louis (2015) hevder at maktdilemmaet som Sarason (1996) og Oettingen (2001) beskriver, er lettere å håndtere dersom man utfordrer siloer som eksisterer mellom aktørene på de ulike nivåene, og mellom nivåene. Læreren som enkeltindivid er viktig, og forskning fremhever læreren som den viktigste påvirkningsfaktoren på elevenes læring (Hattie, 2009). Likevel påvirkes undervisningskvaliteten av mer enn den enkelte lærers kunnskap og erfaring. Den påvirkes i stor grad av det profesjonelle læringsfellesskapet og den kulturen som eksisterer, og som styrker både individuell og kollektiv utvikling (Louis, 2015).

\section{Profesjonelle læringsfellesskap og skolekultur}

I kraft av at skoler er institusjoner der mennesker samles, vil det nødvendigvis dannes sosiale grupper og kulturer. Profesjonelle læringsfellesskap utvikles og 
institusjonaliseres derfor innenfor en kultur, en kode eller et klima som finnes i alle skoler (Arfwedson, 1984; Grosin, 1991; Hargreaves, 1997) En skolekultur består av tradisjoner, verdier, oppfatninger og handlingsmønstre som alle lærere i den enkelte skole må forholde seg til og blir påvirket av. Denne kulturen eller koden kan defineres som et aggregat av retningsgivende tolknings- og handlingsprinsipper som omfatter alt av betydning for skolens virke, arbeidsplassforhold og problemer (Arfwedson, 1984). Skolekulturen er en måte å tenke og handle på som enhver skolevirkelighet fremkaller hos de som arbeider der. Denne forståelsen innebærer at kulturen vil påvirke lærernes måte å undervise på, og hvordan de samhandler og forholder seg til kollegaer (Hargreaves, 1996).

Det er grunn til å anta at et profesjonelt læringsfellesskap ikke bare utfordrer den enkelte lærers subjektive oppfatninger og handlingsmønstre, men også den eller de kulturene som eksisterer i den enkelte skole. Det profesjonelle læringsfellesskapet kan slik utfordre og endre verdier og oppfatninger som ligger i kulturen og som sterkt påvirker enkeltlærere. Profesjonelle læringsfellesskap handler dermed ikke bare om å utfordre subjektive oppfatninger, men likeledes om å utfordre etablerte kollektive oppfatninger og handlingsmønstre i den enkelte skole.

\section{Metode}

Det ble i 2016 gjennomført en elektronisk kartleggingsundersøkelse blant alle grunnskoler i Hedmark fylke i forbindelse med innovasjons- og forskningsprosjektet «Kultur for læring» (Nordahl et al., 2018). Senter for praksisrettet utdanningsforskning (SePU) ved Høgskolen i Innlandet var ansvarlig for gjennomføringen av undersøkelsen, og det er resultatene fra denne som er utgangspunkt for studiens analyser.

\section{Utvalg}

Studien tar utgangspunkt i lærervurderinger fra alle barneskolene i Hedmark. Skoler med færre enn 10 lærere er utelatt fra analysene av metodiske hensyn. Få informanter gir brede konfidensintervall og gjør det vanskelig å trekke sikre slutninger når det gjelder skolegjennomsnitt og variasjon (Skog, 2004). Endelig datagrunnlag for studiens analyser består av vurderinger fra 1152 lærere fra 57 barneskoler.

For å besvare studiens forskningsspørsmål er det gjort et strategisk utvalg for å undersøke variasjon mellom skoler med sterke og svake profesjonelle læringsfellesskap. 20 skoler med 372 lærervurderinger er valgt ut for å maksimere variasjonen (Johannessen et al., 2016): Lærervurderinger fra de ti barneskolene med høyest gjennomsnittsskår innen variabelen profesjonelle læringsfellesskap er kategorisert i skolegruppe 1 (169 lærere), og lærersvar fra de ti barneskolene med lavest gjennomsnittsskår er kategorisert i skolegruppe 2 (203 lærere). Av hensyn 
til studiens formål er det vesentlig å sammenligne så like skoler som mulig med tilfeldig elevgrunnlag og det er derfor gjort en sammenligning av foreldrenes utdanningsnivå. Her viser variansanalyser (ANOVA) ingen signifikante forskjeller mellom skolegruppe 1 og skolegruppe $2(\mathrm{~F}(2,18)=0,177, \mathrm{p}<0,675$. Cohens $d=0,05$ ).

En forutsetning for sterke profesjonelle læringsfellesskap er at lærerne har tid til denne formen for samarbeid (Hargreaves \& Shirley, 2012). Ut fra dette kan det være hensiktsmessig å undersøke om skolegruppene har like forutsetninger når det gjelder lærertetthet. Grunnskolenes informasjonssystem (GSI) viser at de 10 skolene i skolegruppe 1 har svakt høyere lærertetthet enn de 10 skolene i skolegruppe 2 (Utdanningsdirektoratet, 2021). Forskjellen utgjør 2,4 \% av totalt årsverk, og dette gir grunn til å anslå at lærertettheten i skolegruppe 1 og skolegruppe 2 er relativt lik.

Utvalget omfatter lærere fra både fådelte, mellomstore og store skoler, og både byskoler og skoler fra mellomstore tettsteder og mindre bygder er representert. Antall lærere per skole varierer fra 10 til 62, og svarprosenten er 96 både for alle 57 barneskolene og for de 20 barneskolene i det strategiske utvalget. Ut fra utvalg og svarprosent bør kunnskapen fra studien være interessant for videre forskning.

\section{Prosedyrer}

Alle lærere ble invitert til å delta i kartleggingsundersøkelsen, og skolene ble oppfordret til å sette av 15-20 minutter av et personalmøte til gjennomføringen. Deltakerne fikk i forkant informasjon om undersøkelsens hensikt og prosedyrer, og de ble forsikret anonymitet. Det ble understreket at deltakelsen var frivillig og at de når som helst kunne trekke seg. Kartleggingsundersøkelsen er godkjent av Norsk senter for forskningsdata (NSD) i samsvar med norsk lov.

\section{Måleinstrument og datagrunnlag}

Lærerne besvarte et elektronisk spørreskjema bestående av 16 spørsmål som kan knyttes til studiens teoretiske rammeverk og forskningsspørsmål. Spørreskjemaet baseres på Grosins (2004) validerte måleinstrument om skolens klima (Hultin et al., 2018), Sørlie og Nordahls (1998) måleinstrument om skolens miljø, samt måleinstrument om undervisningspraksis utviklet av Nordahl (2018), Nordahl et al. (2015) og Aasen et al. (2014) basert på Hattie (2013) og Marzano og Pickering (2011).

Det er gjennomført faktoranalyse med bruk av Principal Component analyse (PCA) med Direct Oblim-rotasjon for å undersøke faktorstrukturen og lage komponenter (indeksvariabler) som forklarer så mye som mulig av den totale variansen i datasettet (se tabell 1). Kaisers kriterium med egenverdi $>1$ er satt som kriterium. Innledende faktoranalyse (PCA) viser to spørsmål som lader svakt, og ut fra en substansiell vurdering tas de ut av datasettet. PCA av de resterende 
14 spørsmålene gir en 3-faktorløsning, og tabell 1 viser en oversikt over måleinstrumentet med tilhørende informasjon ${ }^{1}$.

Tabell 1. Måleinstrument og datagrunnlag

\begin{tabular}{|c|c|c|c|c|c|c|}
\hline Variabler & Kilde & $\begin{array}{l}\text { Antall } \\
\text { spørsmål }\end{array}$ & Skala & $\begin{array}{l}\text { Cronbachs } \\
\text { alfa }\end{array}$ & $\begin{array}{l}\text { Forklart } \\
\text { varians (\%) }\end{array}$ & $\begin{array}{l}\text { Faktor- } \\
\text { ladning }\end{array}$ \\
\hline $\begin{array}{l}\text { Profesjonelle } \\
\text { læringsfellesskap }\end{array}$ & Grosin (2004) & 6 & $1-4$ & 0,83 & 30,0 & $0,616-0,841$ \\
\hline $\begin{array}{l}\text { Undervisnings- } \\
\text { praksis }\end{array}$ & $\begin{array}{l}\text { Aasen et al. } \\
\text { (2014), Nordahl } \\
\text { et al. (2015), } \\
\text { Nordahl (2018) }\end{array}$ & 5 & $1-5$ & 0,77 & 45,3 & 0,669-0,701 \\
\hline $\begin{array}{l}\text { Profesjons- } \\
\text { tilfredshet }\end{array}$ & $\begin{array}{l}\text { Sørlie \& } \\
\text { Nordahl (1998) }\end{array}$ & 3 & $1-4$ & 0,69 & 54,7 & $0,606-0,843$ \\
\hline
\end{tabular}

Tre komponenter gir 54,7 \% forklart varians. Dette innebærer at en stor andel varians forsvinner, men tatt i betraktning at datasettet har et bredt spekter av spørsmål, vurderes andelen forklart varians som tilfredsstillende. Reliabilitetsanalyser er gjennomført for å måle indikatorsettenes indre konsistens, og resultatene viser at Cronbachs alfa varierer fra 0,69 til 0,83 for alle indeksvariablene. Ifølge Christophersen (2013) anses dette som tilfredsstillende for surveyundersøkelser.

\section{Profesjonelle lceringsfellesskap}

Den første indeksvariabelen består av seks spørsmål som kan betraktes som en operasjonalisering av fenomenet profesjonelle læringsfellesskap (Stoll et al., 2006). Skalaen går fra 1 til 4 ( 1 = passer ikke så godt, 2 = passer noenlunde, 3 = passer godt, 4 = passer meget godt). Lærerne besvarer spørsmålene: «I denne skolen samarbeider vi lærere i stor grad om innhold og metoder i undervisningen», «På denne skolen er det et gjensidig forpliktende samarbeid mellom lærerne om de fleste forhold som vedrører undervisningen», «I denne skolen har lærerne et felles forpliktende ansvar i forhold til alle elever i skolen», «I denne skolen støtter og hjelper lærerne hverandre for å forstå og løse problemer i klassa eller med elever som forstyrrer undervisningen», «Lærerne er enige om hva som er uakseptabel elevatferd», «I denne skolen tar lærerne også ansvar for de elevene som de selv ikke underviser». Høyere verdi innebærer sterkere profesjonelle læringsfellesskap.

\section{Undervisningspraksis}

Indeksvariabelen undervisningspraksis består av fem spørsmål om sentrale læringsutbyttevariabler som differensiering av undervisning og utvikling av ulike læringsstrategier for alle elever. Skalaen går fra 1 til 5 ( 1 = Nei, aldri, 2 = Sjelden,

\footnotetext{
${ }^{1}$ Faktortabell kan etterspørres ved henvendelse til forfatterne.
} 
3 = Av og til, 4 = Ofte, 5 = Ja, alltid). Lærerne besvarer spørsmålene: «Jeg gjennomfører undervisningen slik at elever med ulike læringsstrategier både får oversikt og dypere kunnskap om faglig tema», «Jeg differensierer det faglige innholdet slik at alle elevers læring er i samsvar med intensjonen for timen», «Jeg har god oversikt over hvilke elever som lærer og ikke lærer i mine timer», «Jeg lærer alle elevene ulike læringsstrategier», «Jeg lærer alle elevene hvordan de skal konsentrere seg og følge med i timene». Høyere verdi indikerer oppfatning om bedre undervisningspraksis.

\section{Profesjonstilfredshet}

Indeksvariabelen profesjonstilfredshet kan teoretisk knyttes til det engelske begrepet self-confidence, et uttrykk for lærerens opplevelse av følelsesmessige balanse i profesjonsutøvelsen og trygghet og selvtillit i undervisningspraksisen (Holland et al., 2012). Skalaen går fra 1 til 4 (1 = passer ikke så godt, 2 = passer noenlunde, 3 = passer godt, 4 = passer meget godt) Lærerne besvarer følgende tre spørsmål: «Jeg har stor tillit til meg selv som lærer», «Jeg klarer å opprettholde ro og orden i klasserommet», «Jeg er entusiastisk og engasjert i mitt arbeid». Høyere verdi indikerer større grad av profesjonstilfredshet.

\section{Manglende data}

Little MCAR-test viser 0,3-1,2 \% manglende data på enkeltspørsmål tilhørende alle inkluderte variabler, noe som anses som liten grad av manglende data i materialet. Det ble gjennomført EM-imputering, med utregning av sannsynligheten for hva informanten ville svart på manglende spørsmål på bakgrunn av de besvarte spørsmålene i skalaen (Graham, 2009, 2012).

\section{Statistiske analyser}

Studien kan betraktes som en tverrsnittstudie og survey, og de statistiske analysene er gjennomført med IBM SPSS 26.

For å få oversikt over datamaterialet er det gjennomført frekvensanalyser på alle variabler, og variansanalyser (Oneway ANOVA) er gjennomført for å undersøke forskjeller mellom skoler. Skoler er kategorisert i skolegruppe 1 og skolegruppe 2 basert på skolenes gjennomsnittsskår på indeksvariabelen profesjonelle lcringsfellesskap. Variansanalyser er gjennomført av skoler både i og mellom skolegruppene. Varians uttrykkes i ustandardisert effektstørrelse Cohens $d$ og klassifiseres av Cohen (1988, s. 26) som liten, moderat eller stor hvis den er lik henholdsvis 0,2, 0,5 eller 0,8. Med utgangspunkt i utvalgsvariabelen profesjonelle lcringsfellesskap er det benyttet variansanalyser for å sammenligne foreldres utdanningsnivå, målt på en skala fra 1 (grunnskole) til 5 (mer enn tre års høyere utdanning).

Korrelasjonsanalyser er gjennomført for å undersøke styrken på systematisk relasjon mellom variablene, både på tvers av skoler og skolegrupper og innenfor hver av skolegruppene. Det er videre gjennomført regresjonsanalyser av alle 
inkluderte indeksvariabler for skolegruppe 1 og skolegruppe 2, med undervisningspraksis som avhengig variabel og profesjonelle læeringsfellesskap og profesjonstilfredshet som forklaringsvariabler. Hensikten med regresjonsanalysene er å undersøke om og i hvilken grad læreres vurdering av profesjonelle læringsfellesskap og profesjonstilfredshet kan forklare læreres vurdering av egen undervisningspraksis i de to skolegruppene. Det er testet for multikollinearitet $(T>0,80)$, heteroskedastisitet, og skjevhet i datamaterialet. Analysene viser at det er en lineær samvariasjon mellom variablene og residualene er normalfordelte. Variablene har akseptable verdier for skjevhet og kurtose med grenseverdier mellom -2 og 2 (George \& Mallery, 2011) (se tabell 2). Alle krav som stilles til regresjonsanalyser er dermed tilfredsstilt (Cohen et al., 2011).

\section{Resultater}

\section{Deskriptive analyser}

Innledende frekvensanalyser viser relativt høy gjennomsnittsskår på samtlige indeksvariabler (se tabell 2). Standardavviket er forholdsvis likt på to av områdene, mens lærervurderingene av profesjonelle læringsfellesskap har noe høyere spredning.

Tabell 2. Frekvensanalyser for profesjonelle læringsfellesskap, profesjonstilfredshet og undervisningspraksis i hele utvalget

\begin{tabular}{lllllllc}
\hline Variabler & $\mathrm{N}$ & $\mathrm{M}$ & St.a. & Min. & Maks. & Skjevhet & Kurtose \\
\hline Profesjonelle læringsfellesskap & 1150 & 3,08 & 0,54 & 1 & 4 & $-0,43$ & 0,03 \\
Profesjonstilfredshet & 1152 & 3,33 & 0,46 & 1,33 & 4 & $-0,24$ & $-0,17$ \\
Undervisningspraksis & 1149 & 4,03 & 0,43 & 2,60 & 5 & 0,07 & $-0,03$ \\
\hline
\end{tabular}

\section{Forskjeller mellom skolegrupper}

På grunnlag av de innledende frekvensanalysene av indeksvariabelen profesjonelle læringsfellesskap er det identifisert ti skoler med høyest gjennomsnittsskår (skolegruppe 1), og ti skoler med lavest gjennomsnittsskår (skolegruppe 2). Grunnleggende frekvensanalyser for hver av disse skolegruppene er vist i tabell 3. 
Tabell 3. Frekvensanalyser for profesjonelle læringsfellesskap, profesjonstilfredshet og undervisningspraksis i skolegruppe 1 og 2

\begin{tabular}{llllllll}
\hline Variabler og skolegruppe & $\mathrm{N}$ & $\mathrm{M}$ & St.a. & Min. & Maks. & Skjevhet & Kurtose \\
\hline \begin{tabular}{l} 
Profesjonelle læringsfellesskap \\
\multicolumn{1}{c}{ Skolegruppe 1 }
\end{tabular} & 164 & 3,44 & 0,45 & 2 & 4 & $-0,79$ & 0,21 \\
$\quad$ Skolegruppe 2 & 192 & 2,69 & 0,55 & 1,17 & 3.83 & $-0,27$ & $-0,27$ \\
$\begin{array}{l}\text { Profesjonstilfredshet } \\
\text { Skolegruppe 1 }\end{array}$ & 165 & 3,39 & 0,44 & 2 & 4 & $-0,38$ & 0,15 \\
$\quad$ Skolegruppe 2 & 192 & 3,30 & 0,44 & 2 & 4 & $-0,06$ & $-0,39$ \\
Undervisningspraksis & & & & & & & \\
$\quad$ Skolegruppe 1 & 164 & 4,08 & 0,46 & 2,80 & 5 & 0,09 & $-0,20$ \\
$\quad$ Skolegruppe 2 & 191 & 3,91 & 0,41 & 2,80 & 5 & 0,04 & $-0,02$ \\
\hline
\end{tabular}

Korrelasjonene mellom indeksvariablene (se tabell 4) er moderate og viser ingen entydige mønstre på at lærere som svarer høyt på en variabel også svarer høyt på en annen og motsatt, selv om tendensen er der. Det er gjennomgående sterkest korrelasjoner i skolegruppe 1. Kvadrerte koeffisienter viser at lærere i gruppe 1 sin vurdering av profesjonelle læringsfellesskap samvarierer med deres vurdering av egen undervisningspraksis tilsvarende $13 \%$, mens samvariasjonen mellom de samme faktorene i skolegruppe 2 er 6 \%. Når det gjelder læreres vurderinger av profesjonelle læringsfellesskap og profesjonstilfredshet viser resultatene en samvariasjon på $12 \%$ for skolegruppe 1 og $3 \%$ for skolegruppe 2. Profesjonstilfredshet har en sterkere sammenheng med undervisningspraksis enn profesjonelle læringsfellesskap i begge skolegruppene, og i skolegruppe 1 er denne sterkest med $23 \%$ samvariasjon.

Tabell 4. Korrelasjonsanalyse i skolegruppe 1 og 2 for profesjonelle læringsfellesskap, profesjonstilfredshet og undervisningspraksis

\begin{tabular}{llccc}
\hline Skolegruppe & Variabler & $\begin{array}{l}\text { Profesjonelle } \\
\text { læringsfellesskap }\end{array}$ & $\begin{array}{l}\text { Profesjons- } \\
\text { tilfredshet }\end{array}$ & $\begin{array}{l}\text { Undervisnings- } \\
\text { praksis }\end{array}$ \\
\hline Skolegruppe 1 & $\begin{array}{l}\text { Profesjonelle } \\
\text { læringsfellesskap }\end{array}$ & - & $0,349^{* *}$ & $0,359^{* *}$ \\
& $\begin{array}{l}\text { Profesjonstilfredshet } \\
\text { Undervisningspraksis }\end{array}$ & $0,349^{* *}$ & - & $0,477^{* *}$ \\
Skolegruppe 2 & $\begin{array}{l}\text { Profesjonelle } \\
\text { læringsfellesskap }\end{array}$ & - & $0,477^{* *}$ & - \\
& Profesjonstilfredshet & $0,172^{*}$ & $0,172^{*}$ & $0,244^{* *}$ \\
& Undervisningspraksis & $0,244^{* *}$ & - & $0,302^{* *}$ \\
\hline
\end{tabular}

$* \mathrm{p}<0,05 . * * \mathrm{p}<0,01$ (2-sidig). 
Variansanalysene viser signifikante forskjeller mellom skolegruppe 1 og 2 på indeksvariabelen profesjonelle læringsfellesskap (se tabell 3): $\mathrm{F}(2,18)=192,2$, $\mathrm{p}<0,01$. Cohens $d=1,19$ og kan betraktes som svært stor forskjell mellom skolegruppene når det gjelder læreres oppfatninger av det profesjonelle læringsfellesskapet. Det er ingen signifikante forskjeller mellom gjennomsnittsskårene for skolene innad i de ulike skolegruppene, og dette bekrefter at skolene statistisk fungerer som gruppeenheter.

Når det gjelder profesjonstilfredshet er det også signifikante forskjeller mellom lærervurderingene i skolegruppe 1 og 2, men forskjellen er liten med Cohens $d=0,21: \mathrm{F}(2,18)=4,1, \mathrm{p}<0,05$. Det er relativt høye gjennomsnittsskårer $\mathrm{i}$ begge skolegruppene. Det samme gjelder for variabelen undervisningspraksis som vurderes relativt høyt av lærerne i begge skolegruppene (se tabell 3). Det er likevel signifikante forskjeller mellom læreres vurdering av egen undervisningspraksis i de to skolegruppene, selv om den kan tolkes som relativt liten med Cohens $d=0,37: \mathrm{F}(2,18)=12,6, \mathrm{p}<0,01$.

\section{Multippel regresjonsanalyse}

For å undersøke om indeksvariablene profesjonelle læringsfellesskap og profesjonstilfredshet har ulik forklaringskraft på læreres vurdering av undervisningspraksis i de to skolegruppene, er det gjennomført multippel regresjonsanalyse, en for hver skolegruppe (se tabell 5). Undervisningspraksis inngår som avhengig variabel, mens profesjonelle laringsfellesskap og profesjonstilfredshet inkluderes som uavhengige variabler, i nevnte rekkefølge.

Tabell 5. Multippel regresjonsanalyse av undervisningspraksis i skolegruppe 1 og 2

\begin{tabular}{lllllll}
\hline \multirow{2}{*}{ Variabler } & \multicolumn{3}{c}{ Skolegruppe 1 } & \multicolumn{3}{c}{ Skolegruppe 2 } \\
\cline { 2 - 7 } & $\mathrm{b}$ & SEb & Beta $(\beta)$ & b & SEb & Beta $(\beta)$ \\
\hline Profesjonelle læringsfellesskap & 0,223 & 0,073 & $0,219^{* *}$ & 0,148 & 0,052 & $0,197^{* *}$ \\
Profesjonstilfredshet & 0,424 & 0,076 & $0,401^{* * *}$ & 0,251 & 0,065 & $0,267^{* * *}$ \\
Justert $\mathrm{R}^{2}$ & & & 0,27 & & & 0,12 \\
\hline
\end{tabular}

$* * \mathrm{p}<0,01 .{ }^{* * *} \mathrm{p}<0,001$.

Økning i den uavhengige variabelen med ett standardavvik gir $\beta$ økning i avhengig variabel. Ifølge regresjonsmodellen øker lærernes vurdering av undervisningspraksis tilnærmet likt for skolegruppene for hver økning i standardavvik for profesjonelle læringsfellesskap. Når det gjelder profesjonstilfredshet er forskjellene betraktelig større. For skolegruppe 1 øker undervisningspraksis med 0,4 standardavvik, men for skolegruppe 2 er økningen betydelig mindre og tilsvarer 0,27 standardavvik. De standardiserte koeffisientene $(\beta)$ viser at læreres vurdering av profesjonstilfredshet betyr mer enn profesjonelle læringsfellesskap når det gjelder deres vurdering av egen undervisningspraksis; dette gjelder i begge skolegruppene. 
Justert $\mathrm{R}^{2}$ viser at regresjonsmodellen kan forklare mer av avhengig variabel $\mathrm{i}$ skolegruppe 1 enn i skolegruppe 2, med henholdsvis $27 \%$ og $12 \%$. Lærere i skolegruppe 1 sin vurdering av profesjonelle læringsfellesskap og profesjonstilfredshet kan forklare opp mot $27 \%$ av variansen i deres vurdering av egen undervisningspraksis, noe som kan betraktes som relativt god andel. Samtidig innebærer dette at det også er andre faktorer utenfor denne modellen som bidrar til å forklare variasjonen i lærernes vurdering av undervisningspraksis, og aller mest for lærervurderingene i skolegruppe 2.

\section{Diskusjon}

Studien tar utgangspunkt i store forskjeller mellom skolene når det gjelder læreres vurderinger av det profesjonelle læringsfellesskapet, et funn som fremgår både av studiens innledende analyser og av tidligere studier om ulike samarbeidskulturer i skoler (Arfwedson, 1984; Jenssen, 2020).

Mellom lærere tilhørende skoler med sterke og svake profesjonelle læringsfellesskap viser studien små forskjeller i lærernes oppfatning av profesjonstilfredshet og relativt små forskjeller i lærernes vurdering av egen undervisningspraksis. Lærerne vurderer både sin profesjonstilfredshet og sin undervisningspraksis som relativt god, uavhengig av styrken de tillegger det profesjonelle læringsfellesskapet. Dette gir ikke grunnlag for å konkludere at profesjonelle læringsfellesskap ikke har betydning for profesjonstilfredshet og undervisningspraksis, ettersom dette ikke er en effektstudie med flere målinger. Vi vet ingenting om læreres tidligere praksis, og det kan være slik at lærere med høy skår på profesjonelle læringsfellesskap har hatt en positiv utvikling av egen undervisningspraksis som følge av det sterke profesjonelle læringsfellesskapet. Det må også tas i betraktning at studien undersøker et relativt smalt område, og at det eksisterer langt flere dimensjoner av undervisningspraksis enn det som måles her.

Funnene kan også tolkes i retning av at en lærer kan utvikle god undervisningspraksis uten bidrag fra profesjonsfellesskapet, for eksempel ved hjelp av egenrefleksjon og økt bevissthet. Dersom det profesjonelle læringsfellesskapet oppleves lite relevant for egen praksis, kan en individuell tilnærming oppleves som en rasjonell og hensiktsmessig strategi. En sterkere samvariasjon mellom undervisningspraksis og profesjonstilfredshet enn mellom profesjonelle læringsfellesskap og profesjonstilfredshet kan underbygge denne forklaringen. Formuleringen av spørsmålene styrker sannsynligheten for at lærere i større grad får styrket sin profesjonstilfredshet som følge av undervisningen enn som følge av profesjonsfellesskapet. Lærere som er engasjerte, har stor grad av tillit til seg selv og som vet de klarer å opprettholde ro og orden, vil sannsynligvis også i større grad våge å prøve ut nye ting i praksis.

En forutsetning for at det profesjonelle læringsfellesskapet skal kunne bidra til praksisendring, er at arbeidet bidrar til refleksjoner som utfordrer selve bruks- 
teoriene (Argyris \& Schön, 1996). Samtidig er det andre sterke krefter som virker inn og som kan forklare hvorfor lærere i sterke profesjonelle læringsfellesskap ikke vurderer undervisningspraksisen sin høyere enn sammenligningsgruppen. Vår praksis, våre mønstre og vår identitet som lærer sitter så sterkt i oss, at det skal mye til for at vi endrer handlinger. Mentale modeller om læreren som autoritet og kunnskapsformidler kan gjøre det vanskelig å endre oppfatning av egen rolle, og det å skulle overføre makt til elevene i form av selvstendighet og selvregulert læring kan oppleves utrygt og tap av kontroll (Sarason, 1996). Det kan også være at endring av undervisningspraksis oppleves som tap av noe læreren selv mener har fungert (Nordahl, 2018; Reeves, 2009). Det tryggeste kan i så tilfelle være å benytte erfaringer som regulator og kilde for justeringer, noe som kan føre til at læringen begrenses til enkeltkretsnivå, slik at man lett havner tilbake i gamle mønstre (Argyris \& Schön, 1996). På den annen side kan det være stor vilje til å utveksle erfaringer og drøfte undervisning i et kollegium, og at lærere ikke nødvendigvis er redde for endringer eller å prøve ut noe nytt, men at det er systematikken over tid som mangler, slik at endringene blir å betrakte som enkelthendelser og løsrevne tiltak.

Ut over sterke indre krefter i form av mentale modeller finnes også sterke ytre krefter som virker inn. Lærere sosialiseres inn og påvirkes av de tolknings- og handlingsprinsipper som råder i skolens kultur og legger føringer for måten de underviser på (Hargreaves, 1996). Skolekoden som utvikles i fellesskapet er et sterkt aggregat og kan virke hemmende på potensielle praksisendringer (Arfwedson, 1984). Relativt stor spredning i læreres vurdering av profesjonsfellesskapet kan tolkes dit hen at det eksisterer ulike kulturer og skolekoder også innenfor samme skole.

Studien kan ikke slå fast et årsak-virkningsforhold mellom læreres vurdering av profesjonelle læringsfellesskap, deres profesjonstilfredshet og hvordan de vurderer egen undervisningspraksis. Sammenhengene mellom variablene er gjensidige og kan i stor grad tolkes i motsatt retning. Det kan for eksempel være slik at dyktige lærere med god undervisningspraksis og høy profesjonstilfredshet bidrar til å styrke det profesjonelle læringsfellesskapet. Det er likevel noen mønstre og sammenhenger som avdekkes i denne studien som støtter kunnskapsgrunnlaget og hypotesen om at profesjonelle læringsfellesskap er en hensiktsmessig strategi for å utvikle undervisningspraksis (Vescio et al., 2008). Analysene viser at indeksvariabelen profesjonelle læringsfellesskap i seg selv har samvariasjon med undervisningspraksis, uansett hvor svak eller sterk undervisningspraksisen vurderes av lærerne. At samvariasjonen ikke er større, er kanskje ikke så urimelig om man ser på variablenes egenskaper. Undervisningspraksis er en individuell variabel, og det er liten grunn til å tro at en kollektiv dimensjon som profesjonelle læringsfellesskap skal kunne forklare så mye i seg selv. Undervisningspraksis uttrykker den enkelte lærers valg av undervisning, og det er flere faktorer som må inkluderes for å kunne forklare variasjonen for denne individuelle variabelen. Variablenes egenskaper kan også bidra til å forklare hvorfor den 
individuelle variabelen profesjonstilfredshet betyr mer for læreres vurdering av undervisningspraksis enn deres vurdering av profesjonelle læringsfellesskap.

Når man knytter profesjonelle læringsfellesskap til læreres vurdering av profesjonstilfredshet, inntrer det relativt store forskjeller mellom skolegruppene. Lærervurderingene av profesjonelle læringsfellesskap og profesjonstilfredshet har sterkere forklaringskraft på læreres vurdering av undervisningspraksis i skoler hvor profesjonsfellesskapet oppfattes som sterkt, med $27 \%$ forklart varians. Dersom man ser nærmere på variablenes egenskaper kan dette betraktes som et interessant funn. Forklaringsvariablene uttrykker fenomener på et refleksivt nivå i form av oppfatninger, refleksjon, samtaler og dialog, og kan ses i sammenheng med Argyris og Schöns (1996) uttalte handlingsteorier. Dette gjelder i særlig grad indeksvariabelen profesjonstilfredshet som kan knyttes til en uttalt handlingsteori i form av læreres egne oppfatninger om seg selv som lærer. I skoler der denne skårer høyt er det lettere å finne sammenheng med de anvendte handlingsteorier, det som foregår i praksis.

Sterkere forklaringskraft i regresjonsmodellen for skoler med høy gjennomsnittsskår på profesjonelle læringsfellesskap bekrefter tidligere forskning om at man i samhandling med andre kan utvikle lærerkompetanse som bidrar til utvikling av undervisningspraksis (Donohoo, 2017; Dunne et al., 2000; Holland et al., 2012; Louis, 2015; Louis \& Marks, 1998). Funnene peker også i retning av at profesjonelle læringsfellesskap utfordrer og endrer den skolekulturen eller den skolekoden som eksisterer i enhver skole (Arfwedson, 1984). Vi kan si at denne skolekoden er en kollektiv måte å tenke og handle på som enhver skole fremkaller hos de som arbeider der, og dermed vil skolekoden og også handlingsmønstrene variere mye fra skole til skole. Ut fra dette kan vi antyde at i skoler med sterke profesjonelle læringsfellesskap vil de pedagogiske drøftingene i profesjonsfelleskapet sannsynligvis utfordre etablerte kollektive og individuelle verdier, oppfatninger og handlingsmønstre og øke mulighetene for dobbelkretslæring (Argyris \& Schön, 1996). I skoler hvor lærere vurderer det profesjonelle læringsfellesskapet som svakt, vil sannsynligvis ikke de kollektive og de individuelle oppfatningene og handlingsmønstrene bli utfordret like sterkt. På grunnlag av dette er ikke utvikling av profesjonelle læringsfellesskap kun et spørsmål om å redusere læreres profesjonelle autonomi og innflytelsen av den privatpraktiserende læreren (Robinson, 2018). Betydningen av profesjonelle læringsfellesskap handler sannsynligvis i stor grad også om å utfordre og endre både kollektive og individuelle verdier, oppfatninger og handlingsmønstre.

\section{Metodiske vurderinger}

Fordelen med denne studien er at det er høy svarprosent både i grunnlagsmaterialet og innad i de studerte skolegruppene. Med profesjonelle læringsfellesskap som utvalgsvariabel kan det likevel hende at man mister viktig informasjon fra lærere som vurderer å ha god undervisningspraksis. Det er i tillegg en svakhet at studien måler et relativt smalt område av undervisningspraksis, og at det er få 
variabler som undersøkes. Moderat forklaringskraft mellom variablene indikerer at det finnes andre faktorer som også har betydning på variasjonen enn de som undersøkes i denne studien. Det kunne blant annet vært interessant å undersøke skoleledelsens rolle i forbedringsarbeidet, og hvor mye tid lærere bruker på kollektive aktiviteter som for eksempel kollegabasert observasjon og veiledning.

Lærerne representerer både store og små barneskoler i både byer og bygder, og det er grunn til å tro at resultatene vil være interessante for andre deler av landet. En utfordring med studien er at mange skoler i Hedmark er små og har få lærere. Med få lærere vil risikoen være større for at resultatene er en konsekvens av tilfeldig variasjon både innad og mellom skoler. For å få med flest mulig av barneskolene ble det satt en nedre grense på ti informanter.

Statistiske analyser viser gode faktorløsninger med tilfredsstillende reliabilitetsverdier. Det er likevel viktig å ta i betraktning at måleinstrumentet har visse svakheter når det gjelder validitet. Variablene er ikke etablerte og validerte skalaer, og det kan hende at skalaen om profesjonelle læringsfellesskap ikke klarer å hente ut bredden av fenomenet på en god nok måte. Skalaen er spisset mot læreres samarbeid om elevene og undervisningen, og har eksempelvis ingen spørsmål som dekker tema som kollegabasert observasjon og veiledning. Det kan også være en svakhet at studien benytter lærervurderte variabler og at den ikke måler læreres undervisningspraksis direkte. Egenvurdering vil normalt sett gi høyere skår enn mer objektive observasjoner. Denne forutsetningen vil uansett gjelde for alle informantene og således ikke være til hinder for å sammenligne lærervurderinger i de ulike gruppene. For fremtidig forskning kunne det vært interessant å supplere det kvantitative datagrunnlaget med observasjoner av undervisning og samarbeidsmøter og med intervju av lærere.

\section{Konklusjon}

Resultatene viser at lærere vurderer sin undervisningspraksis som relativt god, uavhengig av styrken de tillegger det profesjonelle læringsfellesskapet. Dette betyr ikke at profesjonelle læringsfellesskap ikke har påvirkning på undervisningspraksis, ettersom studien ikke kan si noe om læreres tidligere praksis. Studiens analyser avdekker derimot noen mønstre og sammenhenger som kan tyde på at det profesjonelle læringsfellesskapet har betydning, og at hypotesen om at læreres tilhørighet i profesjonelle læringsfellesskap påvirker læreres undervisningspraksis, til dels bekreftes.

Studien viser sterkere sammenhenger og mønstre mellom variabler i skoler hvor lærerne oppfatter sterke profesjonelle læringsfellesskap. I disse skolene kan lærernes vurdering av det profesjonelle læringsfellesskapet og deres vurdering av profesjonstilfredshet $\mathrm{i}$ langt større grad forklare deres vurdering av undervisningspraksis, sammenlignet med skoler hvor lærerne vurderer det profesjonelle læringsfellesskapet som svakt. I denne sammenhengen vil det være vesentlig å 
forstå utvikling av profesjonelle læringsfellesskap som noe mer enn å redusere læreres profesjonelle autonomi og den privatpraktiserende lærers innflytelse (Robinson, 2018). Det handler i stor grad også om å utfordre og endre både kollektive og individuelle verdier, oppfatninger og handlingsmønstre. Skolekulturen har sannsynligvis betydning for hvordan man opptrer som enkeltlærer i møte med elevene. Hvordan denne kulturen formes og utvikles, kan ifølge Jenssen (2020) i stor grad forklares av skolens pedagogiske ledelse, og det vil være vesentlig for fremtidig forskning å se nærmere på skoleledelsens rolle og betydning for utvikling av profesjonelle læringsfellesskap, læreres profesjonstilfredshet og undervisningspraksis.

\section{Om forfatterne}

Mette Marit F. Jenssen er PhD-stipendiat ved Høgskolen i Innlandet og tilknyttet forskergruppen Senter for praksisrettet utdanningsforskning. Hennes doktorgradsprosjekt er knyttet til FoU-prosjektet «Kultur for læring» i tidligere Hedmark fylke. Hennes forskningsinteresser er utdanningsledelse og profesjonelle læringsfellesskap i skolen.

Institusjonstilknytning: Fakultet for lærerutdanning og pedagogikk, Senter for praksisrettet utdanningsforskning (SePU), Høgskolen i Innlandet, Postboks 400, 2418 Elverum, Norge.

E-post: mette.jenssen@inn.no

Thomas Nordahl er professor i pedagogikk og leder av Senter for praksisrettet utdanningsforskning ved Høgskolen i Innlandet og professor II ved Aalborg Universitet. Hans forskningsinteresser er utdanningsledelse, inkludering i skolen, kjønnsforskjeller og sosial reproduksjon i utdanningssystemet.

Institusjonstilknytning: Fakultet for lærerutdanning og pedagogikk, Senter for praksisrettet utdanningsforskning (SePU), Høgskolen i Innlandet, Postboks 400, 2418 Elverum, Norge.

E-post: thomas.nordahl@inn.no

\section{Referanser}

Arfwedson, G. (1984). Hvorfor er skoler forskjellige? Tanum-Norli.

Argyris, C. \& Schön, D. A. (1996). Organizational learning II: Theory, method, and practice. Addison-Wesley.

Christophersen, K.-A. (2013). Introduksjon til statistisk analyse: regresjonsbaserte metoder og anvendelser. Gyldendal Akademisk.

Cohen, J. (1988). Statistical power analysis for the behavioral sciences (2. utg.). Lawrence Erlbaum.

Cohen, L., Manion, L. \& Morrison, K. (2011). Research methods in education. Routledge. 
Crossan, M. M., Lane, H. W. \& White, R. E. (1999). An Organizational Learning Framework: From Intuition to Institution. Academy of Management Review, 24(3), 522-537. https://doi.org/10.5465/amr.1999.2202135

Dahl, T., Klewe, L. \& Skov, P. (2004). En skole i bevæegelse: evaluering af satsning på kvalitetsudvikling i den norske grundskole. Danmarks Pædagogiske Universitets Forlag.

Donohoo, J. (2017). Collective efficacy: how educators' beliefs impact student learning. Corwin.

DuFour, R., DuFour, R., Eaker, R. \& Many, T. (2010). Learning by doing: a handbook for professional learning communities at work. Solution Tree Press.

DuFour, R. \& Marzano, R. J. (2015). Ledere af læering. Dafolo.

Dunne, F., Nave, B. \& Lewis, A. (2000). Critical friends groups: Teachers helping teachers to improve student learning. Phi Delta Kappa International Research Bulletin, 28, 9-12. https://www.schoolreforminitiative.org/wpcontent/uploads/2014/02/Dunne_et_al_2000.pdf

Easterby-Smith, M., Lyles, M. A. \& Tsang, E. W. K. (2008). Inter-Organizational Knowledge Transfer: Current Themes and Future Prospects. Journal of Management Studies, 45(4), 677-690. https://papers.ssrn.com/sol3/papers.cfm?abstract_id=1128719

Fullan, M. (2014). A dra i samme retning: et skolesystem som virker. Kommuneforlaget.

George, D. \& Mallery, P. (2011). SPSS for Windows step by step: a simple guide and reference 18.0 update (11. utg.). Allyn \& Bacon.

Graham, J. W. (2009). Missing Data Analysis: Making It Work in the Real World. Annual Review of Psychology, 60(1), 549-576. https://doi.org/10.1146/annurev.psych.58.110405.085530

Graham, J. W. (2012). Missing Data: Analysis and Design. Springer.

Grosin, L. (1991). School Climate, Achievement and Behavior in Eight Swedish Junior High Schools. Revision of a paper presented at the 4th Annual Meeting of the International Congress for School Effectiveness and Improvement, Cardiff, Wales, UK. https://files.eric.ed.gov/fulltext/ED361873.pdf

Grosin, L. (2004). Skolklimat, prestation och anpassning i 21 mellan- och 20 högstadieskolor. Stockholms Universitet, pedagogiska institutionen.

Hargreaves, A. (1996). Lœrerarbeid og skolekultur: lcereryrkets forandring i en postmoderne tid. Ad Notam Gyldendal.

Hargreaves, A. (1997). Cultures of Teaching and Educational Change. I B. J. Biddle, T. L. Good \& I. F. Goodson (red.), International Handbook of Teachers and Teaching (bd. 3, s. 1297-1319). Springer.

Hargreaves, A. \& Fullan, M. (2014). Arbeidskultur for bedre læering i alle skoler: hva er nødvendig lærerkapital? Kommuneforlaget.

Hargreaves, A. \& Shirley, D. (2012). Den fjerde vei: en inspirasjon til endring i skolen. Gyldendal Akademisk.

Hattie, J. (2009). Visible learning: A synthesis of over 800 meta-analyses relating to achievement. Routledge.

Hattie, J. (2013). Synlig læring for læerere: Maksimal effekt på læering. Cappelen Damm Akademisk.

Holland, K., Middleton, L. \& Uys, L. (2012). Professional confidence: A concept analysis. Scandinavian journal of occupational therapy, 19(2), 214-224. https://pubmed.ncbi.nlm.nih.gov/21728746/

Huber, G. P. (1991). Organizational learning: The Contributing Processes and the Literature. Organization Science, 2(1), 88-115. https://www.researchgate.net/publication/215439842_Organizational_Learning_The_Con tributing_Processes_and_the_Literatures 
Hultin, H., Ferrer-Wreder, L., Eichas, K., Karlberg, M., Grosin, L. \& Galanti, M. R. (2018). Psychometric Properties of an Instrument to Measure Social and Pedagogical School Climate Among Teachers (PESOC). Scandinavian Journal of Educational Research, 62(2), 287-306. https://doi.org/10.1080/00313831.2016.1258661

Jenssen, M. M. F. (2020). Profesjonelle læringsfellesskap og pedagogisk skoleledelse. I K. Smith (red.), Validity and value of teacher education research: NAFOL 2019 (s. 131154). Fagbokforlaget.

Johannessen, A., Christoffersen, L. \& Tufte, P. A. (2016). Introduksjon til samfunnsvitenskapelig metode (5. utg.). Abstrakt.

Kunnskapsdepartementet (2017). Overordnet del - verdier og prinsipper for grunnoppleringen.

https://www.regjeringen.no/contentassets/53d21ea2bc3a4202b86b83cfe82da93e/overordn et-del---verdier-og-prinsipper-for-grunnopplaringen.pdf

Laursen, P. F. (2015). Er Hattie og co. gyldige i Danmark? Paideia, (9), 34-41. https://tidsskrift.dk/Paideia/article/view/130111

Levin, B. (2013). To know is not enough: research knowledge and its use. Review of Education, 1(1), 2-31. https://doi.org/10.1002/rev3.3001

Louis, K. S. (2008). Creating and Sustaining Professional Communities. I R. Coles \& A. Blankenstein (red.), Sustaining Learning Communities (s. 41-57). Sage.

Louis, K. S. (2015). Linking leadership to learning: state, district and local effects. Nordic Journal of Studies in Educational Policy, 2015(3), 7-17. https://doi.org/10.3402/nstep.v1.30321

Louis, K. S. \& Marks, H. M. (1998). Does Professional Community Affect the Classroom? Teachers' Work and Student Experiences in Restructuring Schools. American Journal of Education, 106(4), 532-575. http://www.jstor.org/stable/1085627

Marzano, R. J. \& Pickering, D. (2011). The highly engaged classroom. Marzano research laboratory.

Nordahl, T. (2018). Inkluderende fellesskap for barn og unge. Fagbokforlaget.

Nordahl, T., Egelund, N., Nordahl, S. Ø. \& Sunnevåg, A.-K. (2018). Kultur for læering i skolen: Hedmark: Rapport fra kartleggingsundersøkelsen T1 (2535-4140978-82-8380041-8). Høgskolen i Innlandet.

Nordahl, T., Sunnevåg, A.-K., Qvortrup, L., Hansen, L. S., Hansen, O., Lekhal, R. \& Drugli, M. B. (2015). Hold ut og hold kursen. Resultater fra kartleggingsundersøkelse i Kristiansand Kommune i 2015. Aalborg Universitetsforlag. https://flikkristiansand.files.wordpress.com/2016/03/kartleggingsundersc3b8kelse-ikristiansand-kommune-2015.pdf

OECD (2010). TALIS 2008: Technical report. OECD. https://www.oecd.org/education/school/44978960.pdf

Oettingen, A. v. (2001). Det pæedagogiske paradoks: Et grundstudie i almen predagogik. Klim.

Opfer, V. D. \& Pedder, D. (2011). Conceptualizing Teacher Professional Learning. Review of Educational Research, 81(3), 376-407. https://www.jstor.org/stable/23014297

Reeves, D. B. (2009). Leading change in your school: How to conquer myths, build commitment, and get results. Association for Supervision and Curriculum Development.

Robinson, V. (2018). Færre endringer - mer utvikling. Cappelen Damm Akademisk.

Rutter, M., Maughan, B., Mortimore, P. \& Ouston, J. (1979). Fifteen thousand hours: Secondary schools and their effects on children. Open Books.

Sarason, S. B. (1996). Revisiting "The Culture of the School and the Problem of Change". Teachers College Press. 
Skog, O.-J. (2004). A forklare sosiale fenomener, en regresjonsbasert tilncrming (2. utg.). Gyldendal Akademisk.

Stoll, L., Bolam, R., McMahon, A., Wallace, M. \& Thomas, S. (2006). Professional Learning Communities: A Review of the Literature. Journal of Educational Change, 7(4), 221258. https://doi.org/10.1007/s10833-006-0001-8

Sørlie, M.-A. \& Nordahl, T. (1998). Problematferd i skolen: Hovedfunn, forklaringer og pedagogiske implikasjoner: Hovedrapport fra forskningsprosjektet «Skole og samspillsvansker» (Bd. 12a/98). Norsk institutt for forskning om oppvekst, velferd og aldring.

Utdanningsdirektoratet (2021). Grunnskolens Informasjonssystem (GSI). https://gsi.udir.no/

Vescio, V., Ross, D. \& Adams, A. (2008). A review of research on the impact of professional learning communities on teaching practice and student learning. Teaching and Teacher Education, 24(1), 80-91. https://doi.org/10.1016/j.tate.2007.01.004

Aasen, A. M., Nordahl, T., Mælan, E. N., Drugli, M. B. \& Myhr, L. (2014). Relasjonsbasert klasseledelse: Et komplekst fenomen (9788276719567). Høgskolen i Hedmark. http://hdl.handle.net/11250/227105 